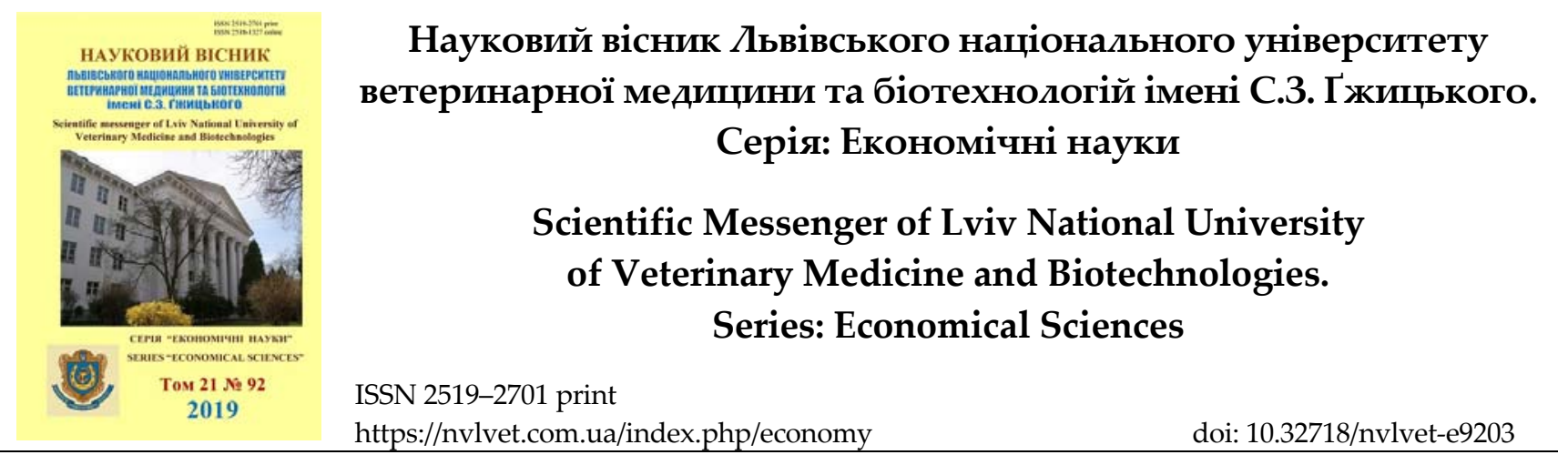

UDC $316.776: 339.138$

\title{
Internet-communications in business digitalization strategies of services enterprises
}

\author{
Y.A. Daynovskyy ${ }^{1}$, L.K. Hlinenko ${ }^{2}$, Y.V. Poliakova ${ }^{1}$ \\ ${ }^{1}$ Lviv University of Trade and Economics, Lviv, Ukraine \\ ${ }^{2}$ National University "Lvivska Polytechnika”, Lviv, Ukraine
}

Article info

Received 18.01.2019

Received in revised form 21.02.2019

Accepted 22.02.2019

Lviv University of

Trade and Economics,

Tuhan-Baranovskyi Str., 10,

Lviv, 79005, Ukraine.

National University

"Lvivska Polytechnika",

Stepana Bandery Str., 12 ,

Lviv, 79013, Ukraine.

Tel. +38-097-771-43-58

E-mail:yddd@ukr.net

Daynovskyy, Y.A., Hlinenko, L.K., \& Poliakova, Y.V. (2019). Internet-communications in business digitalization strategies of services enterprises. Scientific Messenger of Lviv National University of Veterinary Medicine and Biotechnologies. Series: Economical Sciences, 21(92), $15-20$. doi: $10.32718 /$ nvlvet-e9203

Digitalization of business in the sphere of services is proved to create new terms, forms and technologies of services rendering and to strengthen the enterprise competitive position, while undue considering the actual tendencies in strategies of Internet-communications development can bring the business of rendering the services of certain type to end in failure. The acceleration of processes of electronization of relations between suppliers and consumers of services is illustrated. Advantages of digital communications over the traditional ones are stated. These advantages are: freedom from territorial limitations for distribution of communication messages, considerably less charges per contact, possibility of feed-back, possibility of real-time monitoring of effeciency of every communication event, easy access of consumers to information regardless of time and place of the consumers residence.Dividing of facilities of Internet-communications into groups by possibility of applying them by the enterprises of service business is carried out. The actual trends of Internet-communications are analysed. It is shown that strategic prospects of chat-bot usage is predetermined by possibility to provide information and communication in 24/7 mode, by the comfort for a client as well as by the considerable economy of resources. Significance for Internetcommunications of such trends as expansion of application of vocal search, complemented and virtual reality, and orientation on mobile devices with geotargetting is emphasized. The importance of business processes automation and of speeding-up the web-site loading is illustrated. The modern Internet user mainly gives preference to viewing the video data instead of re-reading the texts what makes investing in development of creative video-content to be very promising. As potential consumers give more credence to the content created by actual consumers, stimulating the users of services to express their opinions and ideas, to place the photo- and video data as well as systematic elimination of the defects indicated in reviews become important direction of Internet-communications development. The native advertising in the Internet and providing of "transparency" of enterprises-service providers for the real and potential clients gain in significance. It is reasoned that the enterprises of service business must take into account in their marketing strategies the objective trends related to the development of digital technologies as well as to the modern features of exceptionally communicative influence on clients; prerequisites for strengthening of this influence are created by possibilities of the Internet use. ing.

Key words: Internet-communications, digitalization of business, strategies, sphere of services, market-

\section{Інтернет-комунікації у стратегіях цифровізації бізнесу підприсмств сфери послуг}

\author{
Ю.А. Дайновський${ }^{1}$, Л.К. Гліненко을. Ю.В. Полякова ${ }^{1}$ \\ ${ }^{1}$ Львівський торговельно-економічний університет, м. Львів, Украйна \\ ${ }^{2}$ Національний університет "Львівська політехніка", м. Львів, Україна
}


Обтрунтовано, щзо цифрровізація бізнесу у сфері послуг створює нові умови, форми і технологї їх надання, зміцнює конкурентні позииії підприємств, а несвоєчасне врахування актуальних трендів у стратегіях розвитку Інтернет-комунікацій може призвести до руйнації бізнесу з надання певного виду послуг. Проілюстровано прискорення процесів електронізації стосунків між надавачами і споживачами послуг. Сформульовано переваги циифрових комунікацій над традиційними: відсутність територіальних обмежень для розповсюдження комунікачійних повідомлень, значно менші витрати у розрахунку на один контакт, можливість зворотного зв'язку, можливість відстежувати результативність кожного комунікаційного заходу у режимі реального часу, легкий доступ споживачів до інформації незалежно від часу і місчя їх перебування. Здійснено поділ засобів Інтернет-комунікацій на групи стосовно можливості їх застосування підприємствами сфери послуг. Проаналізовано актуальні тренди Інтернет-комунікацій. Показано, щзо стратегічна перспективність використання чат-ботів зумовлюється можливістю надання інформації $і$ спілкування у режимі 24/7, зручністю для клієнта, значною економією ресурсів. Підкреслено роль для Інтернет-комунікацій таких трендів, як розширення застосування голосового пошуку, доповненої $i$ віртуальної реальності, орієнтації на мобільні пристрої з геотаргетингом. Проілюстрована важливість автоматизації бізнес-процесів, підвищення швидкості завантаження сайтів. Сучасний користувач Інтернету переважно віддає перевагу переглядові відеоматеріалу замість перечитування тексту, щзо зумовлює перспективність інвестування у створення креативного відео-контенту. Оскільки підвищеною довірою потенційних споживачів користується контент, створений фактичними споживачами, важливим напрямом стає стимулювання користувачів послуг щзодо висловлення думок, розмішення фото- і відеоматеріалів, а також систематична робота над виправленням недоліків, вказаних у відгуках. Підвищується роль нативної реклами в Інтернеті і забезпечення "прозорості" підприємств-надавачів послуг для своїх реальних і потенційних клієнтів. Обтрунтовано, щуо підприємства сфери послуг повинні враховувати у свойх маркетингових стратегіях об' єктивні тренди, пов'язані як з розвитком власне ичифрових технологій, так $і$ з сучасними особливостями суто комунікативного впливу на клієнтів, поштовх для посилення якого створюють можливості використання Інтернету.

Ключові слова: Інтернет-комунікації, циифровізація бізнесу, стратегї, сфера послуг, маркетинг.

\section{Вступ}

Цифрова революція започаткувала нові способи ведення бізнесу, які швидко руйнують традиційні варіанти обслуговування і маркетингові технології у багатьох галузях діяльності. Діджиталізація створює ланцюгову реакцію інновацій, що усувають з ринку перевантажених активами гравців, бізнес-моделі яких не пристосовані до нових реалій.

Надання багатьох видів послуг орієнтується нині на глобальний ринок, відповідно зростання кількості їхніх споживачів відбувається завдяки міжнародній мобільності. Глобальні комунікації стають каталізаторами розвитку системи обслуговування, що абсолютно очевидно на прикладі відомих Інтернетмагазинів світового масштабу, систем Інтернетпродажу автобусних, залізничних і авіа білетів, систем замовлення готельних номерів та ін. Саме глобальні комунікації дали потужний поштовх розвитку ITгалузі в Україні, вони дають можливість працювати віртуальним науково-дослідницьким i проектним групам, що скорочує тривалість процесів досліджень і розробок та зменшує пов'язані з ними витрати. Набула розвитку міжнародна онлайн-освіта, створюються віртуальні університети, які об’єднують університети різних країн у віртуальну мережу.

Відомим є явище скорочення циклів життя інновацій від їх проектування до повномасштабного впровадження, зрілості, старіння і до заміни новими, більш прогресивними інноваціями. У сфері послуг це може стосуватися не тільки і не стільки самої сутності конкретних послуг, а й форм їх надання і засобів просування на ринок, комунікацій з потенційними клієнтами. В епоху всепроникаючої цифровізації втрата часу при впровадженні інновацій, відсутність належних реакцій на актуальні тренди може швидко призвести до руйнації усього бізнесу з надання певного виду послуг.

Отже, вкрай важливим є своєчасне врахування у маркетингових стратегіях підприємств сфери послуг цифрової компоненти, необхідності та конкретних засобів Інтернет-комунікацій, які розвиваються і в недалекому майбутньому можуть стати вирішальним фактором ринкового успіху або провалу.

Метою статті $\epsilon$ визначення пріоритетних напрямів розвитку Інтернет-комунікацій для їх врахування у стратегіях цифровізації бізнесу підприємств сфери послуг.

\section{Матеріал і методи досліджень}

Дослідження базувалося на матеріалах публікацій з проблем Інтернет-комунікацій і цифровізації бізнесу у сфері послуг, фактологічному, статистичному матеріалі, даних досліджень українських і зарубіжних науковців. У процесі дослідження було використано методи порівняльного аналізу, синтезу, узагальнення, абстрактно-логічний, системний підхід до дослідження економічних процесів.

\section{Результати та їх обговорення}

Прискоренню процесів електронізації стосунків між надавачами і споживачами послуг сприяють постійне підвищення показників забезпечення населення електронними засобами та інтенсивності їх застосування. Зараз в Україні на першому місці серед Інтернет-девайсів - смартфон (57\% користувачів), на другому - домашній ноутбук (45\%), на третьому - стаціонарний домашній компютер (39\%). Рівень Інтернет-проникнення у травні 2018 р. становив 64,9\%. В містах 3 населенням до 100 тис. мешканців регулярними користувачами Інтернет вважають себе $65 \%$, а в містах з населенням понад 100 тис. мешканців - 75\% (Tsyfrovyi rozryv ..., 2018). За підсумками 2017 р. вже 3,5\% роздрібного обороту в Україні склали онлайнпродажі (Social'nye seti ..., 2018).

У світі рівень проникнення соціальних мереж оцінюється у 42\%, причому цей відсоток постійно зростає. Так, у 2018 порівняно з 2017 р. кількість користувачів соціальних мереж зросла на 13\%. В Україні протягом 2017 року кількість користувачів Facebook збільшилася на 67\%, Instagram - вдвічі (Social'nye seti ..., 2018). 
Відбувається процес глобальної діджиталізації бізнесу. Це дає можливість з мінімальними витратами досягати окремих нішевих ринків і отримувати відгуки на пропозиції у режимі реального часу, що дозволяє оперативно налаштовувати маркетингові стратегії на досягнення найбільших ефектів. Згідно з даними досліджень підприємства, що використовують у своїй діяльності цифровий маркетинг, є на 26\% ефективнішими порівняно 3 тими, які не застосовують цифрових технологій (Stasiuk, 2018).

Цифровий маркетинг і цифрові комунікації вважаються ширшими поняттями, ніж Інтернетмаркетинг i Інтернет-комунікації (Oklander \& Romanenko, 2015), адже цифровими є, зокрема, SMS i MMS-повідомлення, локальний зв'язок між комунікаційними засобами (Bluetooth), локальні мережі, цифрове телебачення, сучасні інтерактивні екрани, POSтермінали, відеокамери та ін.

Прикро, що в окремих наукових працях і навіть в урядових документах про важливість цифровізації послуг або забувають, або виносять ці питання в окремі блоки, які виглядають відірваними від загального змісту відповідних праць. Проілюструємо це на прикладі галузі освітніх послуг. Так, у Національній доповіді про стан і перспективи розвитку освіти в Україні, викладеній на 448 сторінках, питанням інформатизації освіти присвячено окремий розділ (4 сторінки), у той же час серед загального переліку стратегічних напрямів сучасної модернізації вищої освіти України і серед невідкладних дій, націлених у майбутнє, не знайшлося місця для інформаційнокомп'ютерних технологій і їх впровадження в освітній процес (Natsionalna dopovid ..., 2016).

Аналогічну картину спостерігаємо у Національній стратегї розвитку освіти в Україні на 2012-2021 роки (Natsionalna stratehiia ..., 2012), де інформатизація освіти знову виноситься в окремий розділ (1,5 сторінки) і водночас ці питання повністю випадають 39 напрямів розвитку вищої освіти і 313 очікуваних результатів реалізації Національної стратегії розвитку освіти. Не згадується цифровізація серед основних тенденцій розвитку ринку продуктів вищої освіти і в окремих наукових публікаціях (Zhehus, 2018).

Визначаючи п'ять кроків для реалізації успішної маркетингової стратегії у сфері освітніх послуг, Ю.З. Драчук і Л.О. Слав’юк три з них безпосередньо пов'язують 3 цифровим маркетингом і цифровими комунікаціями. Насамперед відзначається використання соціальних медіа, оскільки потенційні здобувачі певних освітніх ступенів віддають перевагу тим освітнім закладам, які потужно представлені у соціальних мережах Facebook, Twitter, YouTube (Drachuk \& Slaviuk, 2018). Аналогічною є ситуація у сфері багатьох інших видів послуг - забезпечення нормального функціонування готельних мереж, транспортних компаній, туристичних фірм, банківських установ сьогодні немислимо без Інтернет-комунікацій.

Засоби Інтернет-комунікацій стосовно можливості їхнього застосування підприємствами сфери послуг можна умовно розподілити на три групи. Перша 3 них - це засоби, які традиційно використовуються у сфері послуг більшістю підприємств, вони забезпечують результативність комунікацій за помірних витрат часу, коштів, інтелектуальних зусиль. До таких засобів можуть бути зараховані Інтернет-реклама, вебпрезентації, розсилка текстової інформації, аудіо- та відео файлів, посилання на Інтернет-ресурси, які вигідно висвітлюють діяльність підприємства, поширення через соціальні мережі даних про поточні події з життя підприємств (презентації, конференції, конкурси, участь у виставках, акційні пропозиції тощо).

До другої групи можна зачислити засоби, які використовуються відносно рідше, вимагають значних інтелектуальних і фінансових витрат, проте потенційно можуть забезпечувати ефект. Це робота з пошукової оптимізації сайтів (яку нині переважно здійснюють тільки найбільш фінансово потужні або технологічно чи інформаційно “просунуті” підприємства), створення спеціальних блогів, форумів. Тут складність полягає у необхідності постійного інформаційного оновлення, знаходженні цікавих тем для спілкування. Залежно від масштабів і профілю діяльності, особливостей контингенту, що обслуговується, нішевої спеціалізації підприємств можуть прийматися різні стратегічні рішення: ці засоби можуть бути доцільними для клініки пластичної хірургії або туристичної фірми, що надає ексклюзивні тури і абсолютно непотрібними для пересічних перукарень чи кафе.

Третя група засобів - це такі, що є популярними в одних сферах обслуговування, але рідко знаходять застосування в інших. Так, Інтернет-стимулювання збуту за допомогою акцій, конкурсів, ігор, вікторин можуть стимулювати споживача зробити разову закупівлю товару, але навряд чи спрацьовуватимуть у таких стратегічно спрямованих послугах, як ріелторські чи освітні. Реклама в мобільних додатках, SMS i MMS-розсилка може стосуватися масових послуг, проте явно не підходить для вузькоспеціалізованих послуг, коли реальною цільовою аудиторією є лише мізерна частка усіх власників мобільних гаджетів (за виключенням ситуацій, коли рекламодавець спроможний технічно виокремити свою цільову аудиторію).

Переведення різних видів послуг у віртуальний формат, як показує практика, спроможне не тільки створювати нові види бізнесу, а й відбирати істотні частки ринку в компаній, що надають ці послуги традиційними способами. За останне десятиріччя 174 стартапи, свідомо обравши стиль диджитал, створили нові галузі із сукупною капіталізацією понад квінтильйон доларів (Didzhytalizatsiia ..., 2015). Компанія Uber, найбільший у світі постачальник послуг таксі, не має жодної машини. Facebook та Twitter, два найпотужніших гравця медіа-простору, не створюють жодного контенту. Alibaba, найдорожча роздрібна компанії сучасності, не має товарних запасів, а Airbnb, провідний постачальник послуг з короткотермінової оренди житла, не володіє нерухомістю. Компанії, що працюють у сфері послуг, повинні бути свідомими того, що ігнорування у стратегіях свого розвитку можливостей віртуалізації, діджиталізації свого бізнесу на певному етапі може загрожувати його повною або принаймні частковою руйнацією.

Проаналізуємо декілька актуальних трендів Інтернет-комунікацій, які обов'язково повинні братися до 
уваги компаніями сфери послуг при формуванні стратегій впровадження цифрових технологій у власний бізнес.

1. Збільшення масштабів застосування чат-ботів.

За прогнозами компанії Gartner, використання чатботів у 2020 р. буде забезпечувати $85 \%$ обсягу послуг взаємодії з клієнтами (Plany na zavtra ..., 2018).

Термін “бот” у виразах Інтернет-бот, www-бот, чат-бот є скороченням від “робот”, тобто, інакше кажучи, це програми-роботи, що використовуються в Інтернеті і діють за певними алгоритмами. Вони можуть виконувати як рутинні операції (типу автоматичних відповідей на електронні листи, відновлення забутих користувачами паролей або виконання ролі віртуального суперника в комп'ютерних іграх), так і складні інтелектуальні процедури спілкування з клієнтами, тому їх розробка межує 3 проблемами створення штучного інтелекту.

Такі програми можуть підбирати варіанти проживання у готелях, придбання транспортних білетів, місць відпочинку і розваг, полегшити вибір мобільного тарифного плану, замовлення доставки товарів додому, таксі, місць у театрах чи ресторанах, можуть виконувати роль фінансового онлайн-консультанта. У сфері послуг з підбору кадрів чат-боти допомагають як працедавцям, так і особам, що шукають роботу аж до проведення співбесіди з кандидатами на вакансії.

Стратегічна перспективність використання чатботів зумовлюється можливістю надання інформації і спілкування у режимі 24/7, зручністю для клієнта, який отримує інформацію безпосередньо при відвідуванні онлайн-ресурсу, неможливістю ситуацій очікування у зв'язку із зайнятістю усіх наявних консультантів, значною економією ресурсів. Прогрес у сфері використання чат-ботів $\epsilon$ незворотним, тому навіть у галузях, де складність і багатоаспектність необхідного спілкування клієнта 3 підприємством-надавачем послуги не дає можливості повною мірою скористатися цим засобом комунікації зараз (наприклад, у сфері банківських послуг) необхідно бути готовими до майбутніх змін і поступового витіснення людей роботами 3 процесу комунікації.

\section{2. Голосовий пошук.}

Вже зараз голосовий пошук використовують 65\% власників смартфонів у світі, серед американських споживачів ним користуються 72\% (Cud, 2018). Дослідження показують, що 71\% користувачів мобільних засобів віддадуть перевагу голосовому пошуку, а не традиційним пошуковим сервісам (Plany na zavtra ..., 2018). За прогнозами до 2020 року половина пошукових запитів буде подаватися з голосу (Trendy digitalmarketinga, 2018).

На ринку з'являється побутова техніка 3 голосовим управлінням. Постійно збільшуються продажі “розумних колонок”, які розбудять власника вранці, повідомлять про останні новини, погоду, корки, нагадають плани на день, замовлять товари чи послуги. 3'являються спеціальні додатки для голосового шопінгу, замовлення їжі.

Очевидно, що клієнт, який буде запитувати голосом, зможе отримати відповідь тільки від тих компаній чи брендів, які сприйматимуть такі запити і бу- дуть спроможними на них відповідати. Відповідно компанії, що не матимуть таких можливостей, поступово втрачатимуть ринок.

3. Доповнена і віртуальна реальність.

Застосування елементів доповненої і віртуальної реальності дає можливість продемонструвати, як саме товар буде взаємодіяти 3 реальністю споживача, наприклад, як саме буде виглядати покупець у відповідному одязі, або елемент меблів у відповідному інтер'єрі. Спеціальні додатки дозволяють віртуально виконати макіяж, перемістити товари 3 онлайнкаталогу в домашню обстановку.

\section{4. Автоматизація бізнес-процесів.}

Штучний інтелект стане незамінним у роботі з великими обсягами інформації для визначення поведінкових сценаріїв клієнтів, вибору все більш складних стратегій персоналізації. Розумний алгоритм допоможе оптимізувати платну рекламу на основі оцінювання іiі результативності в режимі реального часу.

У автоматизований режим переходить процес закупівлі рекламних майданчиків і розміщення на них конкретних рекламних оголошень. Набирає обертів практика автоматизованих гуртових закупівель рекламних площ i ефірного часу 3 метою їх подальшого перепродажу конкретним рекламним агентствам або рекламодавцям (медіабаінг). За прогнозами - вже в 2019 р. таким способом буде продаватися 2/3 рекламних місць (Trendy digital-marketinga, 2018).

5. Орієнтація на мобільні пристрої 3 геотаргетингом.

У сучасному переповненому пропозиціями послуг ринковому середовищі дуже важливим стає не тільки якість послуги, а й своєчасність іiі пропозиції. Пошук і точне вираховування тих “мікромоментів", коли варто запропонувати певну послугу найкращим чином можна здійснити саме на основі цифрових технологій, які дають можливість у автоматичному режимі відслідковувати багато різних параметрів зовнішнього середовища. Наприклад, готельна мережа Red Roof Inn використовує інформацію про затримки авіарейсів для пропонування авіапасажирам своїх послуг. Використання таких мікромоментів збільшило кількість клієнтів у відповідні дні на 60\% (Plany na zavtra ..., 2018). Мережа застосовує також таргетинговану рекламу, орієнтовану на водіїв, на підставі обробки даних про дорожній рух.

6. Підвищення швидкості завантаження сайтів.

Досвід показує, що навіть незначні затримки при завантаженні сайтів призводять до втрат клієнтів: $53 \%$ людей готові вийти 3 сайту, який завантажується понад 3 секунди. Якщо ж середній час завантаження скорочується до 0,5 секунди, то трафік сайту збільшується в середньому на 10\%, а конверсія в Інтернетмагазинах (відношення кількості купівель, замовлень, підписок, реєстрацій, переходів за посиланнями до загальної кількості відвідувачів) зростає на 20\% (Plany na zavtra ..., 2018).

7. Використання відеоконтенту.

Ha YouTube щодня переглядається понад мільярд годин відео (Stasiuk, 2018). За різними оцінками зараз користувачі Інтернету в середньому від 45 хвилин до години присвячують перегляду відеоматеріалів, а до 
2020 року ця тривалість досягне 84 хвилин (Plany na zavtra ..., 2018; Cud, 2018).

Сучасний користувач Інтернету в переважній більшості випадків віддає перевагу переглядові відеоматеріалу замість перечитування тексту. За прогнозами - відеоконтент вже у 2019 році буде становити 8085\% усього Інтернет-трафіку (Trendy digitalmarketinga, 2018; Cud, 2018). Додавання короткого відео в еmail-розсилку підвищує рівень переходів 3 листа у 3-4 рази (Trendy digital-marketinga, 2018). Отже, інвестування у створення креативного, цікавого, інформативного відеоконтенту є стратегічно перспективним напрямом розвитку Інтернет-комунікацій.

8. Зростання цінності користувацького контенту.

Однією з найбільших проблем маркетингових комунікацій $є$ проблема довіри потенційного клієнта до інформації про пропозиції. Для перевірки достовірності розміщеної інформації онлайн-відвідувач переважно звертається до перегляду споживацького контенту, тобто відгуків попередніх користувачів. 85\% онлайн-аудиторії настільки ж довіряє користувацьким відгукам, як і рекомендаціям своїх знайомих (Plany na zavtra ..., 2018), проте загальний користувацький контент порівняно з рекомендаціями знайомих $\epsilon$ неспівмірно ширшим за рівнем охоплення всіх можливих послуг. Тому дуже важливими є стратегічні рішення компаній щодо формування відповідного споживацького контенту. Це, по-перше, систематична робота над виправленням недоліків, вказаних у відгуках користувачів, i, по-друге, стимулювання користувачів щодо висловлення думок, розміщення фото- i відеоматеріалів, які переважно позитивно характеризуватимуть компанію. Другий напрям можуть ефективно реалізовувати, наприклад, туристичні фірми, заохочуючи туристів до розміщення найкращих фотографій і відео, відзнятих протягом відповідного туру. Варто також враховувати, що користувацькі відгуки порівняно з традиційним контентом є набагато дешевшим комунікаційним засобом.

9. Збільшення частки реклами нативного характеру.

Перенасичення Інтернет-трафіка рекламою викликає у користувача небажання знайомитися з іï змістом, тому важливим трендом $є$ подання рекламної інформації у такий спосіб, щоби користувач не ідентифіковував іiі відразу як власне рекламу і не відмовлявся на цій основі від ознайомлення з контентом. Нативна реклама повинна більш органічно вписуватись у контент, набувати форми і характеристик платформи, на якій розміщується. Це вимагатиме від маркетологів збільшення креативності за рахунок зменшення агресивності.

10. Намагання фірм бути більш прозорими для клієнтів.

На підставі вивчення більш ніж двох тисяч відповідей респондентів компанія Label Insight виявила, що 94\% покупців лояльніші до брендів, які є прозорими (Trendy didzhital-marketinga ... dlja malogo biznesa, 2018). С багато прикладів, які свідчать про те, що прозорість стає важливим чинником збільшення продажів. Так, коли компанія Affordable Language Services почала публікувати на своєму сайті використовувану нею модель ціноутворення, кількість лідів протягом місяця подвоїлася (Trendy didzhitalmarketinga ... dlja malogo biznesa, 2018). Важко визначити усі параметри бажаної для клієнта прозорості, проте переважно як стратегічні рішення у цьому плані радять стимулювати клієнтів давати свої відгуки, спеціально організовувати для цього певні платформи, форуми, слідкувати за “свіжістю” відповідних відгуків, просити клієнтів про написання відгуків 3 подробицями співробітництва, деталізацією його позитивних і негативних аспектів, подавати інформацію про заходи компанії у зв'язку з негативними відгуками або висловленими побажаннями клієнтів, розповідати про події, пов'язані 3 пропонованими товарами і послугами, публікувати свої ціни у порівнянні 3 цінами інших ринкових пропозицій, моделі ціноутворення, розміщувати інформацію про своїх співробітників, включно з фото- і відеоматеріалами. Прозорість продає - ця теза має враховуватись як у конкретних діях, так і при формуванні стратегій розвитку.

\section{Висновки}

Отже, підприємства сфери послуг, які прагнуть стабільно розвиватись і утримувати стійкі конкурентні позиції, повинні обов'язково слідкувати за сучасними тенденціями цифровізації бізнесу і розвивати сучасні технології Інтернет-комунікацій. Вони повинні враховувати у своїх маркетингових стратегіях об'єктивні тренди, пов'язані як 3 1) розвитком власне цифрових технологій, так і з 2) сучасними особливостями суто комунікативного впливу на клієнтів, поштовх для посилення якого дають можливості використання Інтернету. До першого з цих напрямів варто зачислити застосування чат-ботів, голосового пошуку, доповненої і віртуальної реальності, автоматизацію бізнес-процесів, орієнтацію на мобільні пристрої 3 гео-таргетингом, підвищення швидкості завантаження сайтів. Другий напрям включає, насамперед акценти на використання відео-контенту, користувацького контенту, нативну рекламу, “прозорість" підприємств-надавачів послуг для своїх реальних і потенційних клієнтів.

Перспективи подальших досліджень. Невпинне прогресування цифровізації бізнесу, пришвидшення його темпів вимагає постійного моніторінгу нових можливостей у сфері Інтернет-комунікацій для їх своєчасного врахування у стратегіях розвитку підприємств сфери послуг.

\section{References}

"Tsyfrovyi rozryv" v Ukraini postupovo zmenshuietsia (2018). Marketingovye issledovanija v Ukraine, 4, 43 (in Ukrainian).

Cud, V. (2018). Internet-marketing v 2019: prognozy i tendencii. https://ain.ua/2018/11/16/internetmarketing-v-2019 (in Russian).

Didzhytalizatsiia: yak ne vtratyty konkurentnu perevahu (2015). http://www.management.com.ua/notes/digitalinnovation.html (in Ukrainian). 
Drachuk, Yu.Z., \& Slaviuk, L.O. (2018). Shliakhy aktualizatsii marketynhu osvitnikh posluh $\mathrm{v}$ umovakh hlobalizatsiinoi ekonomiky. Marketynh ta lohistyka v systemi menedzhmentu. Tezy dop. XII Mizhnar. nauk.-prakt. konf. Lviv: Vydavnytstvo Lvivskoi politekhniky, 80-83 (in Ukrainian).

Natsionalna dopovid pro stan i perspektyvy rozvytku osvity v Ukraini (2016). Nats. akad. ped. nauk Ukrainy; za zah. red. V.H. Kremenia. Kyiv: Pedahohichna dumka, 448 (in Ukrainian).

Natsionalna stratehiia rozvytku osvity v Ukraini na 2012 2021 roky (2012). https://dniokh.gov.ua/wpcontent/uploads/2014/12/4455.pdf (in Ukrainian).

Oklander, M.A., \& Romanenko, O.O. (2015). Spetsyfichni vidminnosti tsyfrovoho marketynhu vid Internet-marketynhu. Ekonomichnyi visnyk Natsionalnoho tekhnichnoho universytetu Ukrainy "Kyivskyi politekhnichnyi instytut", 12, 362-371 (in Ukrainian).

Plany na zavtra: 9 trendov, kotorye izmenjat digitalmarketing V 2019 godu (2018). https://www.thinkwithgoogle.com/intl/ru-ru/insightstrends/user-insights/trends-2019 (in Russian).
Social'nye seti: i ob'ekt, i instrument marketingovyh issledovanij (2018). Marketingovye issledovanija $\mathrm{v}$ Ukraine, 4, 16-25 (in Russian).

Stasiuk, K.Z. (2018). Osnovni tendentsii tsyfrovoho marketynhu. Marketynh ta lohistyka v systemi menedzhmentu. Tezy dop. XII Mizhnar. nauk.-prakt. konf. Lviv: Vydavnytstvo Lvivskoi politekhniky, 225-226 (in Ukrainian).

Trendy didzhital-marketinga v 2019 godu dlja malogo biznesa (2018). https://convertmonster.ru/blog/ marketing-blog/trendy-digital-marketinga-v-2019godu-dlya-malogo-biznesa (in Russian).

Trendy digital-marketinga v 2019 godu (2018). http://blog.yudjes.com.ua/trendy-digitalmarketinga-v2019-godu-art5211 (in Russian).

Zhehus, O.V. (2018). Rozvytok rynku produktiv vyshchoi osvity v Ukraini: stan i naslidky dlia zakladiv vyshchoi osvity. Marketynhova osvita v Ukraini. Tezy IV mizhnar. nauk.-prakt. konf. K.: KNEU, 18-21 (in Ukrainian). 